\title{
Private International Law in Mainland China, Taiwan and Europe
}

\author{
Ed. by Jürgen Basedow and Knut B. Pißler \\ [Internationales Privatrecht auf dem chinesischen Festland, in Taiwan und Europa.]
}

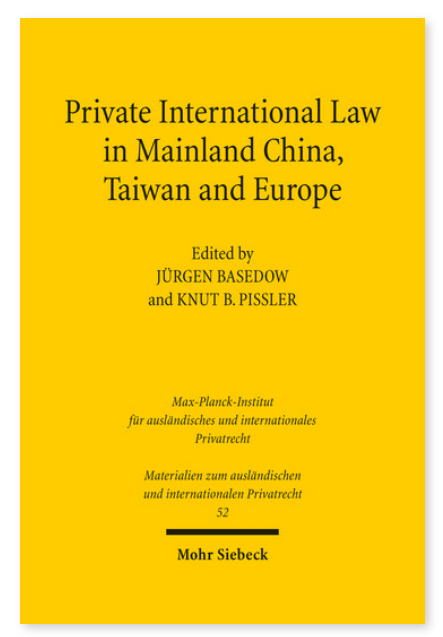

2014. XIII, 470 Seiten. MatIPR 52

ISBN 978-3-16-153357-0

DOI 10.1628/978-3-16-153357-0 eBook PDF

ISBN 978-3-16-153356-3

Leinen $99,00 €$
Veröffentlicht auf Englisch.

Während der letzten Jahrzehnte wurde das internationale Privatrecht Ziel intensiver Kodifikationsbemühungen. Zahlreiche Länder begannen eine umfassende Gesetzgebung auf diesem Gebiet zu verabschieden. Zu diesen Ländern zählen das chinesische Festland und Taiwan. Der vorliegende Band versammelt die Beiträge einer Konferenz über Kollisionsnormen, die in Europa, dem chinesischen Festland und in Taiwan eingeführt wurden sowie englische Übersetzungen der einschlägigen chinesisch-sprachigen Rechtstexte.

\section{Inhaltsübersicht}

Part 1: Jurisdiction, Choice of Law, and the Recognition of Foreign Judgments in Recent Legislation Jin Huang: New Perspectives on Private International Law in the People's Republic of China - Rong-Chwan Chen: Jurisdiction, Choice of Law and the Recognition of Foreign Judgments in Taiwan - Stefania Bariatti: Jurisdiction, Choice of Law and the Recognition of Foreign Judgments in Recent EU Legislation

Part 2: Selected Problems of General Provisions

Weizuo Chen: Selected Problems of General Provisions in Private International Law: The PRC Perspective - Rong-Chwan Chen: General Provisions in the Taiwanese Private International Law Enactment 2010 - Jürgen Basedow: The Application of Foreign Law - Comparative Remarks on the Practical Side of Private International Law

\section{Part 3: Property Law}

Huanfang Du: The Choice of Law for Property Rights in Mainland China: Progress and Imperfection - Yao-Ming Hsu: Property Law in Taiwan- Louis d'Avout: Property Law in Europe

\section{Part 4: Contractual Obligations}

Qisheng He: Recent Developments of New Chinese Private International Law With Regard to Contracts - David J. W. Wang: The Revision of Taiwan's Choice-of-law Rules in Contracts - Pedro A. De Miguel Asensio: The Law Applicable to Contractual Obligations. The Rome I Regulation in Comparative Perspective

Part 5: Non-Contractual Obligations Guoyong Zou: The Latest Developments in China's Conflicts Law for Non-contractual Obligations - En-Wei Lin: New Private International Law Legislation in Taiwan: Negotiorum Gestio, Unjust Enrichment and Tort - Peter Arnt Nielsen: Non-Contractual Obligations in the European Union: The Rome II Regulation

Part 6: Personal Status (Family Law/Succession Law)

Yujun Guo: Personal Status in Chinese Private International Law Reform - Hua-Kai Tsai: Recent Developments in Taiwan's Private International Law on Family Matters - Katharina Boele-Woelki: International Private Law in China and Europe:A Comparison of Conflict-of-law Rules Regarding Family and Succession Law

Part 7: Company Law

Tao Du: The New Chinese Conflict-of-law Rules for Legal Persons: Is the Middle Way Feasible? - Wang-Ruu Tseng: Private International Law in Taiwan - Company Law - Marc-Philippe Weller: Companies in Private International Law - A European and German Perspective

\section{Part 8: International Arbitration}

Song Lu: China - A Developing Country in the Field of International Arbitration - Carlos Esplugues Mota: International Commercial Arbitration in the EU and the PRC: A Tale of Two Continents or $28+3$ Legal Systems

Knut Benjamin Pißler ist Professor für chinesisches Recht an der Universität Göttingen, Lehrbeauftragter an den Universitäten Göttingen und Köln sowie wissenschaftlicher Referent am Max-Planck-Institut für ausländisches und internationales Privatrecht in Hamburg.

Jürgen Basedow (1949-2023)

1997-2017 Director em. of the Max Planck Institute for Comparative and International Private Law and Professor of Law, University of Hamburg.

Jetzt bestellen:

https://mohrsiebeck.com/buch/private-international-law-in-mainland-china-taiwan-and-europe-9783161533570?no_cache=1 order@mohrsiebeck.com

Mohr Siebeck GmbH \& Co. KG

Postfach 2040

D-72010 Tübingen

info@mohrsiebeck.com

www.mohrsiebeck.com 
Telefon: +49 (0)7071-923-17

Telefax: +49 (0)7071-51104

Mohr Siebeck GmbH \& Co. KG

Postfach 2040

D-72010 Tübingen

info@mohrsiebeck.com

Mohr Siebeck

www.mohrsiebeck.com 